\title{
微粒子セメントを用いたグラウトの細砂地盤への 間隙浸透形態に関する微視的研究
}

\author{
米田俊一*.岡林茂生 ${ }^{* *}$. 田村昌仁***. \\ 森麟****
}

\begin{abstract}
従来セメントミルク等の懸濁系グラウトの注入は困難といわれていた透水係数が $10^{-3} \mathrm{~cm} / \mathrm{sec}$ のオーダーの細砂地盤に対し，セメント粒子径を変えたセメントミルクお よびセメントー水ガラス系グラウトを注入し, 掘り出し調査によって浸透状態を比較し た。また, 室内基礎実験および微視的観察と併せて, グラウト処理土の強度, 透水係数 等の工学的特性と地盤構成粒子間隙におけるグラウトの浸透形態の関連を検討した.

Key Words : grout, groutability, fine cement, permeation, filling, strength, pore size distribution, micro structure
\end{abstract}

\section{1. まえがき}

都市土木分野の注入工法は，主として仮設工事段階の 一時的止水や補強が注入目的とされ，従来，水ガラスに 代表される溶液系グラウトが用いられる場合が多かった が，最近では巨大構造物の建設が増加し，注入工法の確 実性が求められるとともに，固結後の強度や耐久性も重 視されるようになっている.

現在使用できる溶液系グラウトは「薬液注入工法によ る建設工事の施工に関する暫定指針（建設省事務次官通 達, 昭和 49年)」により, 強度や耐久性に問題のある水 ガラス系に限られている.これらの問題点を改善するた めに, 従来から, 夕゙ム基礎分野の注入なゼで強度, 耐久 性に信頼性のあるセメント系グラウトを水ガラスと併せ た懸濁系グラウトが用いられているが, 粒子分散系の宿 命で溶液系グラウトに比べて浸透性に関して不利な面も あった，近年では，超微粒子セメントの開発によって両 者の差は縮小しつつあるが, 浸透挙動および浸透性能に ついては不明な点が多く，注入現象あるいは注入機構の 解明に至っていない，また，その結果，配合および施工 などの合理的設計施工方法も未だ確立されていない。

本研究は, 超微粒子セメントをグラウト材料としてさ らに改善・改良することを目的としている。このために は, 注入現象の実態を正確に把握し, 材料特性と浸透特 性あるいは改良効果との関係を明確にし, 得られた情報 を材料開発に応用することが重要なプロセスとなる.

ところで各種の地盤に対して，セメント懸濁系グラウ 卜の浸透の可否を論じた研究, 例えば, グラウタビリティ の研究などは従来より多数発表されているが1),2), 注入

*工博 宇部興産（株） セメント事業部 技術部長 ( (140 東京都品川区東品川2-3-11 UBE ビル)

**宇部興産（株）セメント事業部開発部製品 G. L.

*** 工博 建設省 建築研究所 第 3 研究部主任研究員 **** 工博 早稲田大学教授 理工学部 土木工学科
機構を明らかにする上で必要な形態調查，すなわち地盤 構成粒子間隙におけるグラウトの浸透形態などを微視的 に観察研究したものは，非常に少ないようである．そこ で, 本研究では, グラウトの注入機構あるいは注入改良 効果を検討するために, グラウト処理土の工学的諸特性 と間隙の微細構造との関連を調べることを研究のねらい とした。すなわち，セメントミルク系 (以下, $\mathrm{CM}$ 系 と略す) とセメントー水ガラス懸濁系 (以下, LW 系 と略す）の 2 種類のグラウトを用いて, 砂層に対する室 内基礎実験および現場注入・掘り出し実験を行い，グラ ウト処理土の強度, 透水性などの工学的性質と固結体内 部の微視的組織との関連について調查研究を行った。

\section{2. 試験地盤，現場実験および室內実験の概要}

\section{（1）試験地盤}

本研究は, 注入材料特性の影響が現れ易いと考えられ る A 地区 (千葉県九十九里町東北部作田川上流域の小支 流が開折した河谷低地）の地盤を試験対象に選び，現場 注入・掘出し調査および室内実験を行った。実験地盤は 成田層亡考えられる洪積層であり, シルト混じりの細砂 が厚く堆積し, 地下水位はほぼ地表面付近にあった。表 -1 に現場注入および試料土の採取を行った深度 6 ～9 $\mathrm{m}$ の土質概要を示す.

\section{（2）使用材料}

室内基礎実験に用いた砂質土は, 注入実験を行った $\mathrm{A}$ 地区の地盤（前述）から採取したものであり，表一1に その物理的性質を併記した.本実験では, 主としてブレー ン比表面積が $10000 \mathrm{~cm}^{2} / \mathrm{g}$ の超微粒子セメント（記号 U）を検討することにし，そのほか比較のために比表面 積 $5650 \mathrm{~cm}^{2} / \mathrm{g}$ の微粒子セメント（記号 F）および普通 ポルトランドセメント（記号 N) を用いた（表一2). 分散剤はコンクリート用高性能減水剂（ナフタレンスル フォン酸ホルマリン高縮合物系) を用い，セメント重量 
表一1＼cjkstart現場注入地盤の土質概要

\begin{tabular}{|c|c|c|c|}
\hline 土質区分 & \multicolumn{2}{|c|}{ 細 } & 砂 \\
\hline$(\mathrm{GL}-\mathrm{m})$ & 6. 5 & 6. $15 \sim 7.15$ & 8. $15 \sim 9.15$ \\
\hline $\mathrm{N}$ 値 & & $27 \sim 40$ & $40 \sim 29$ \\
\hline 土粒子密度 $\left(\mathrm{g} / \mathrm{cm}^{3}\right)$ & 2. 650 & 2. $680 \sim 2.689$ & 2. $698 \sim 2.710$ \\
\hline 含水比 & 16.2 & $24.0 \sim 23.8$ & $27.0 \sim 29.4$ \\
\hline 乾燥密度 $\left(\mathrm{g} / \mathrm{cm}^{3}\right)$ & 1. 40 & & \\
\hline 間弥此 & 0.89 & & \\
\hline 細粒分含有率 （\%) & & 7 & $8 \sim 9$ \\
\hline 均等係数 & & 2. $47 \sim 2.67$ & 2. $58 \sim 2.54$ \\
\hline 加積通過 $15 \%$ 径 (mm) & 0.17 & & \\
\hline 透水係数 $\quad(\mathrm{cm} / \mathrm{sec})$ & $\begin{array}{r}2.1 \times 10^{-3} \\
-J I S A 1218\end{array}$ & $\begin{array}{l}8.53 \times 10^{-3} \\
\text { 一現場透水- }\end{array}$ & \\
\hline
\end{tabular}

注）太枠内：室内実験使用土の性質

\begin{tabular}{|c|c|c|c|c|}
\hline \multirow[t]{2}{*}{ 記号 } & \multirow[t]{2}{*}{ 比重 } & \multirow{2}{*}{$\begin{array}{l}\text { ブレーン比表 } \\
\text { 面積 }\left(\mathrm{cm}^{2} / \mathrm{g}\right)\end{array}$} & \multicolumn{2}{|c|}{ 加積通過重量粒径 $(\mu \mathrm{m})$} \\
\hline & & & 50年通過径 & 85\%通過径 \\
\hline u & 2. 94 & 10000 & 3.4 & 6.2 \\
\hline $\mathbf{F}$ & 2. 96 & 5650 & 11.0 & 22.0 \\
\hline $\mathrm{N}$ & 3. 13 & 3230 & 15.1 & 35.0 \\
\hline
\end{tabular}

注）レーザー回折式粒度分析計による

表一3 現場実験に用いたグラウト配合

\begin{tabular}{|c|c|c|c|c|c|c|c|c|}
\hline \multirow[t]{2}{*}{ 記号 } & \multirow{2}{*}{$\begin{array}{l}\text { セxト } \\
\text { 種類 }\end{array}$} & \multirow{2}{*}{$\begin{array}{l}\text { tx’r } \\
\text { 沙 } \\
\text { w/c (\%) }\end{array}$} & \multirow{2}{*}{$\begin{array}{l}\text { 七x朴 } \\
\text { 沙 } \\
\text { 水が }\end{array}$} & \multicolumn{2}{|c|}{ 単 位 量 } & \multicolumn{2}{|c|}{$\left(\mathrm{kg} / \mathrm{m}^{3}\right)$} & \multirow{2}{*}{$\begin{array}{c}\text { 粘 度 } \\
(\mathrm{cp})\end{array}$} \\
\hline & & & & セx外 & 水がラス & 水 & 分散剤 & \\
\hline CM-N & $\mathrm{N}$ & 800 & & 120 & & 960 & 2. 4 & 1.0 \\
\hline CM-F & $\mathrm{F}$ & 800 & $1: 0$ & 120 & 0 & 960 & 2. 4 & 1.0 \\
\hline CM-4 & U & 400 & & 230 & & 920 & 4. 6 & 1.2 \\
\hline CM-8 & U & 800 & & 120 & & 960 & 2. 4 & 1.0 \\
\hline LW-4 & $U$ & 400 & $1: 1.7$ & 85 & 748 & 499 & 1.7 & 7.8 \\
\hline LW-8 & $U$ & 800 & $1: 1$ & 60 & 594 & 605 & 1.2 & 5.0 \\
\hline
\end{tabular}

注） $*$ 水ガ 万人原液（ $\mathrm{SiO}_{2}: \mathrm{Na}_{2} \mathrm{O}:$ 水=32.1:15.3:52.6、重量\%）

の $2 \%$ 添加した. 水ガラスは地盤注入材用低モル品 $\left(\mathrm{SiO}_{2} / \mathrm{Na}_{2} \mathrm{O}=2.15\right)$ を濃度 $75 \mathrm{vol} \%$ に希釈して使用 した.

\section{（３）現場注入・掘出し調査}

注入は 2 重管ダブルパッカー工法を採用し, 所定深度 6, $7,8 \mathrm{~m}$ でのポイント注入を行った. 表一1に示すよ

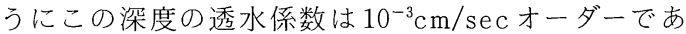
り，微粒子セメントを用いたグラウトの浸透限界に近い 条件と想定された ${ }^{21}$.そこで本実験のグラウトは表一3 に示すように, 従来の経験を参考として, 水セメント比 400，800\% の超微粒子セメントを用いたセメントミル クと水ガラス溶液を，それぞれ，1:1，1:1.7に併せ， ゲルタイムを同じにした希薄懸濁系の LW 系グラウト を実用性の観点で取りあげることとした，また，セメン トの粒子径を変えた CM 系もこれら LW 系と比較のた め検討することとした。注入において，CM 系グラウ トは配管が 1 本の 1 ショットで，LW 系は別々に調製 した 2 液を配管途中で 1 本に合流させる 1.5 ショットで 圧送した． CM 系の注入速度は $6 \boldsymbol{\ell} /$ 分，LW 系は 10
表一4 現場実験における注入条件

\begin{tabular}{|c|c|c|c|c|c|c|c|}
\hline \multirow[t]{2}{*}{ 記号 } & \multicolumn{2}{|c|}{ 注入速度 (1/min) } & \multirow{2}{*}{$\begin{array}{c}\text { が淤 } \\
\text { 温 度 } \\
\left({ }^{\circ} \mathrm{C}\right)\end{array}$} & \multirow{2}{*}{$\begin{array}{l}\text { ゲル } \\
\text { タイ } \\
\text { (min.) }\end{array}$} & \multirow{2}{*}{$\begin{array}{l}\text { 注入深 } \\
{ }_{(\mathrm{m})}{ }_{(\mathrm{m})}\end{array}$} & \multirow{2}{*}{$\begin{array}{l}\text { 注入圧 } \\
\text { (Mpa) }\end{array}$} & \multirow{2}{*}{$\begin{array}{l}\text { 注 } \\
\text { 会 } \\
\text { (min.) }\end{array}$} \\
\hline & セメントルク & 水ガう久 & & & & & \\
\hline $\begin{array}{l}\text { CM-N } \\
\text { CM-F } \\
\text { CM-4 } \\
\text { CM-8 }\end{array}$ & 6 & - & $\begin{array}{l}20.4 \\
19.7 \\
20.1 \\
19.8\end{array}$ & - & $\begin{array}{l}-8 \\
-6 \\
-6 \\
-7\end{array}$ & $\begin{array}{l}1.2 \\
0.6 \\
0.5 \\
0.7\end{array}$ & 17 \\
\hline $\begin{array}{l}\text { LW-4 } \\
\text { LW-8 }\end{array}$ & $\begin{array}{l}4 \\
5\end{array}$ & $\begin{array}{l}7 \\
5\end{array}$ & $\begin{array}{l}23.0 \\
22.0\end{array}$ & $\begin{array}{l}35 \\
42\end{array}$ & $\begin{array}{l}-7 \\
-8\end{array}$ & $\begin{array}{l}1.1 \\
1.2\end{array}$ & $\begin{array}{l}9 \\
10\end{array}$ \\
\hline
\end{tabular}

表一5 混合成形供試体および現場注入固結体に関する実験概要

\begin{tabular}{|c|c|c|c|c|}
\hline グラウト記号 & CM-2, CM-4 & CM-6 & CM-8 & LW-4, LW-8 \\
\hline セメント種類 & u & u & $\mathrm{N}, \mathrm{F}, \mathrm{U}$ & U \\
\hline $\begin{array}{c}\mathrm{Gc} の W / \mathrm{C} \quad(\%) \\
\text { Gc: } \mathrm{Gg} \\
\text { (容積比) }\end{array}$ & $\begin{array}{c}200, \quad 400 \\
1: 0\end{array}$ & $\begin{array}{l}600 \\
1: 0\end{array}$ & $\begin{array}{l}800 \\
1: 0\end{array}$ & $\begin{array}{c}400,800 \\
1: 1.7(\mathrm{LW}-4) \\
1: 1 \quad(\mathrm{LW}-8)\end{array}$ \\
\hline てん充率 $(\%)$ & $1007550-$ & 1007550 & - & $1007550-$ \\
\hline $\begin{array}{r}\text { 圧縮強度 3日 } \\
7 \text { 日 } \\
28 \text { 日 } \\
70 \sim 90 \text { 日 }\end{array}$ & $\begin{array}{lll}0 & \\
0 & 0 & 0 \\
0 & 0 & 0\end{array}$ & $\begin{array}{lll}0 & & \\
0 & 0 & 0 \\
0 & 0 & 0\end{array}$ & (2) & $\begin{array}{lll}0 & & \\
0 & 0 & 0 \\
0 & 0 & 0 \\
& & 0\end{array}$ \\
\hline $\begin{array}{r}\text { 透水係数 7日 } \\
\text { 过吟 } 1 \text { 28日 } \\
70 \sim 90 \text { 日 }\end{array}$ & $\begin{array}{l}0 \\
0\end{array}$ & $\begin{array}{ll}0 & 0 \\
0 & 0\end{array}$ & \multicolumn{2}{|c|}{ 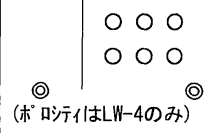 } \\
\hline てん充率測定 & & & (0) & (0) \\
\hline 顕微鏡観察 & $\begin{array}{r}\stackrel{(9)}{(C M-4)} \\
\text { ( }\end{array}$ & 0 & (2) & $\stackrel{(}{(L W-4)}^{\circ}$ \\
\hline
\end{tabular}

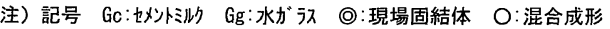

$11 \ell /$ 分の一定に制御し，合計注入量は全てのケースで $100 \ell$ とした. 表一 4 に注入条件等を示す. 注入施工後, 約 50〜70日の間に施工場所周囲に鋼矢板を打込み, G. L. $-6 \mathrm{~m}$ までは重機によって, それ以深は人力掘削 と水洗を併用して掘り下げ，グラウト浸透の状況を調査 した. 洗い出した固化体は地上に搬出し, 詳細な外観観 察のほか表一 5 の試験に供した。

\section{（4）室内実験（混合成形供試体）}

グラウトと試料土（グラウト未浸透の現場土）を混合 し，現場土と同等の間隙比となるように締め固めた供試 体の強度, 透水係数および微細構造を検討した（表一5).

セメントミルクは, 水, 分散剤, セメントの順でジュー サミキサーに投入し， $6000 \mathrm{rpm}$ で 15 秒間， $12000 \mathrm{rpm}$ で 30 秒間かく汼して調製した。混合成形供試体は直径 $5 \mathrm{~cm}$, 高さ $10 \mathrm{~cm}$ の円柱体とし, セメント物理試験方 法（JIS R 5201）に準じ，あらかじめ調製したセメン トミルク，水ガラス希釈液および試料土を容量 $2 \ell$ のモ ルタルミキサーで混合したのち，モールドに 2 層に分け て詰め，各層に $730 \mathrm{~g}$ のおもし $\left(37 \mathrm{gf} / \mathrm{cm}^{2}\right)$ をのせた 状態でモールド側面を軽打することによって締め固め た。供試体は温度 $20^{\circ} \mathrm{C}$ 恒温室でビニール密封養生を 行った.

本実験でグラウトと土の混合成形試験体を採用した理 


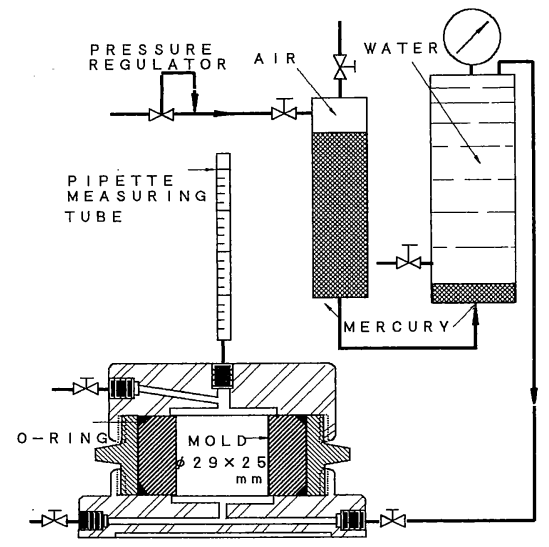

図一1 透水試験装置 (API Spec. 10)

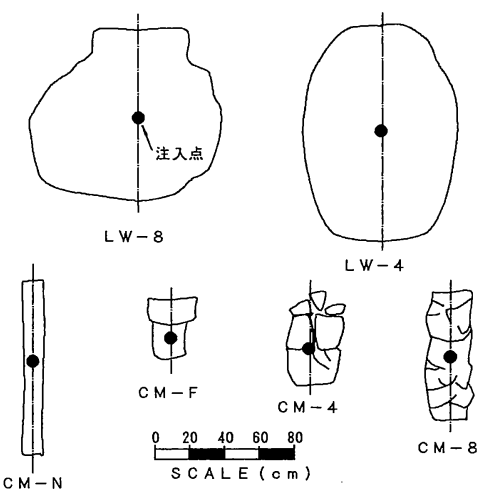

図一2 掘出し固結体の外観スケッチ 由は，a）グラウトが希薄であり，成形締め固め度に影 響しないであろうこと，b）供試体各部でのグラウトて ん充率が均一になること, c) 所定濃度のグラウトの間 隙内部てん充率の大きさを任意の大きさにコントロール できることなどからである。

なお，上記（３），（4）における CM 系供試体の水 セメント比は, LW 系のセメント濃度と同一水準にす ると強度が著しく弱くなるため, 現場実験では 800, $400 \%$, 室内実験では 600 から 200\% の強度試験が可能 な範囲とした.このため, 䀣濁物質の単位量, すなわち 単位セメント量 (グラウト容積 $1 \mathrm{~m}^{3}$ 当たりのセメント 重量）はLW 系よりも CM 系の方が高くなっている.

\section{（5）混合成形供試体および現場注入固結体の試験方} 法

a）一軸圧縮強さ，透水係数およびてん充率

一軸圧縮試験では，テンシロン万能材料試験機（オリ エンテック製）を使用してひずみ制御（ひずみ速度 $1 \%$ ノ分）で載荷した．透水性は，コアサンプラーで抜取っ た直径 $3 \mathrm{~cm}$, 長さ $2.5 \mathrm{~cm}$ の供試体を API (American Petroleum Institute) の油井セメント規格の Spec. 10 に準じて試験した. API セメント透水試験装置を図一1 に示す。てん充率は, 一軸圧縮試験終了後の供試体中央 部から採取した断片を $105^{\circ} \mathrm{C} て ゙ 24$ 時間乾燥したのち粉 末試料とし, ポルトランドセメントの化学分析方法 (JIS R 5202) に従って Naおよび $\mathrm{Ca}$ 成分を分析し, 分析値 を基に土粒子間陌に対するてん充率を算出した.

b) 微細組織の解析

一軸圧縮試験後の供試体中心部, 現場注入固結体の ボーリングコア中心部から採取した断片，および試料土 について, 間隙量および間隙径分布 (以下単に, ポロシ ティと表す）を水銀圧入式ポロシメーター（湯浅アイオ ニクス製，測定可能細孔半径 $100 \sim 0.0018 \mu \mathrm{m} ）$ により 測定した. 試料土のポロシティは佐藤らの方法 ${ }^{31}$ に準じ, $\phi 0.8 \times 1.0 \mathrm{~cm}$ 銅パイプに試料土を封入して試験した.

光学顕微鏡観察用薄片試料の前処理では, 試料の急激
な乾燥による微細ひび割れを防ぐために $20^{\circ} \mathrm{C}, 20 \%$ R.H.の $\mathrm{N}_{2}$ ガス気流中での乾燥 (2 日間) を行った. また，できるだけ含水状態に保持した試料の微細組織を 観察するため, 低真空走査型電子顕微鏡観察を行った. この場合, 観察の直前に試料の真空処理 $(0.4 \sim 0.6$ $\mathrm{mmHg})$ を 3 分間行い, 全ての観測を 10 分で終了する こととした.

\section{3. 現場注入固結体の形状についての検討}

図一2に掘出した固結体の外観スケッチを示す.

固結体の形状寸法は各々のグラウトの浸透性を反映し たものとなった.このうち CM 系では, セメント粒径 の大きい CM-N は，グラウトが注入パイプと地盤との 隙間に長さ $1 \mathrm{~m}$ にわたって拘留され, 注入点からの均 等浸透がみられない，浸透性はセメント粒子径が小さく なるにつれて良くなる傾向がある. 例えば CM-4の固 結体容積および半径 (平均円筒半径) は $42 \ell, 15 \mathrm{~cm}$ で ある. セメントUを用いたCM系の水セメント比の相 違による影響は明瞭でない. 注入対象土の間隙率を 0.47 , 注入グラウト量を $100 \ell$, グラウトの間隙てん充 率を $100 \%$ とする時の球状固結体容積は $213 \ell$ (半径 37 $\mathrm{cm})$ であるので, CM 系の浸透性はさらに改善が望ま れる. 一方, LW 系の注入容積は CM 系より大きく, 注入孔を軸としてほぼ円筒形の固結体が得られた。 LW-8 の固結体容積および円筒換算半径は $574 \ell, 45.1$ $\mathrm{cm}$, 同様に LW=4では $524 \ell, 37.3 \mathrm{~cm}$ であった. なお, これらの間隙各部でのグラウトてん充状態を一様と仮定 したときの平均てん充率は両固結体ともに約 $40 \%$ とな り，この数值は未充てん部がかなり残存していることを 示す.グラウト自体の粘性, ゲルタイムあるいは注入速 度などの施工条件にも係わると思われるが, LW 系で は, 結果的に，このように未充てん部分を残しながら浸 透が進行することが, 固結体のみかけ容積を大きくして いる.

懸濁系グラウトの浸透性の違いはグラウタビリティ 


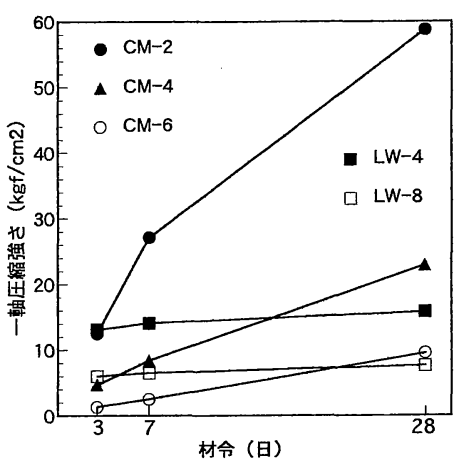

図一3 混合成形供試体の一軸圧縮強さ

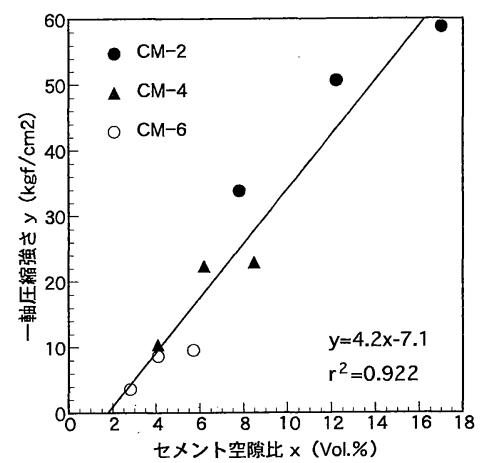

図一4 混合成形供試体 (CM 系) のセメント 空隙比と一軸圧縮強さ（材令 28 日）

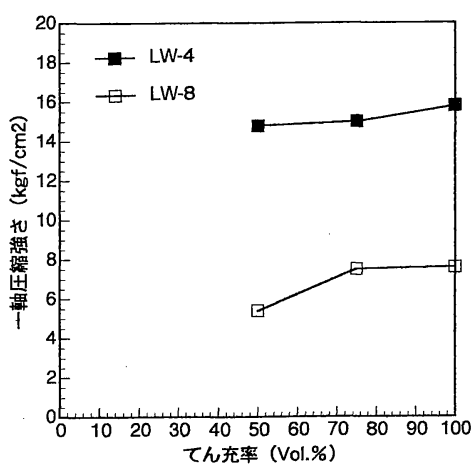

図一5 混合成形供試体 ( $\mathrm{LW}$ 系) のてん充率 と一軸圧縮強さ（材令 28 日）
(加積通過率15\%の地盤粒子径／同 $85 \%$ のセメント粒 子径）で説明可能である. 今回の試験に用いたセメント のグラウタビリティは，N，F，Uのそれぞれについて， 5, 8, 27 であり, グラウタビリティが約 10 以下では浸 透が困難であるという従来の知見とほぼ対応してい る ${ }^{2,+4)}$. LW 系が CM 系より浸透性が優れる原因には, LW 系は水ガラスと併用するため媒体の粘度が高いこ と, および短時間でゲル化することから懸濁物質の固液 分離が少ないことが挙げられる. 材料分離は注入中に目 詰まり現象を助長し, あるいは注入後の間陌内部での不 均一分布を引き起こし, グラウトの浸透性および間隙に 充てんされた注入液の形態変化に影響することが推察さ れる. LW 系は，このような材料分離が少ないことに 加えて, 媒体の粘性が高いために媒質であるセメント粒 子同士, あるいはセメント粒子と土壌粒子との接近が妨 げられてセメントの再凝集や通過メディアへの抑留が少 なくなることによって，あるいは水ガラスの潤滑作用な ビによって, 浸透性が良好になったものと推察できる.

なお, 本研究の LW 系の懸濁物質濃度であるセメン 卜濃度は CM 系よりも低いが, これも目詰りの影響度 を小さくし, 現場グラウト処理土の固結半径を大きくし た要因と考えられる。媒体の粘度および懸濁物質濃度の 影響は今後の研究課題である.

\section{4. 混合成形供試体および現場注入固結体の諸 性質}

前章で述べたようにグラウト中の懸濁物質であるセメ ントの分離沈降特性, 目詰りは, 間隙内部でのてん充率 や充てん形態に影響し, さらにはグラウト処理土の強度 および透水係数なよ゙の工学的性質を左右すると考えられ る.この章では, 主として超微粒子セメントUを用い たグラウトの間隙てん充率の大きさが強度および透水係 数に及ぼす影響を検討する。

\section{（1）一軸圧縮強さ}

図一3に示すように CM 系混合成形供試体の一軸圧 縮強さは一般のコンクリートと同様に水セメント比が小
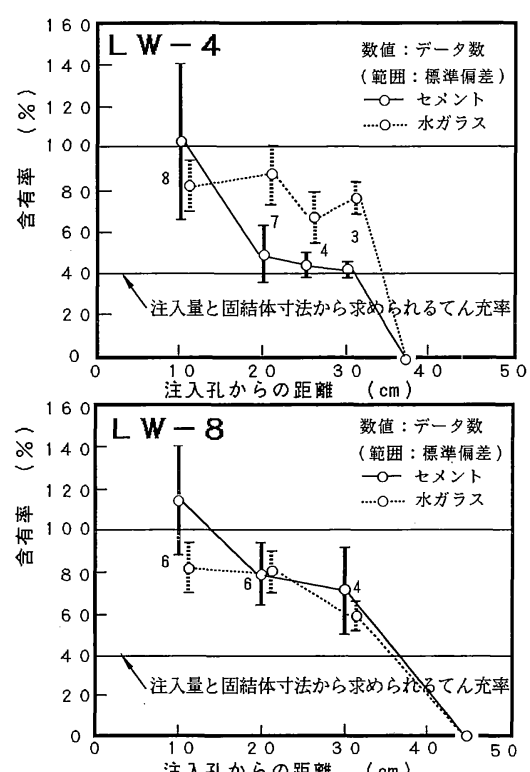

図一6 掘出し固結体の注入孔からの距離と成分含有率

さいほぼ高く, 材令 28 日までほぼ直線的に強度が増加 する傾向がある. LW 系は水ガラスのゲル化に伴って 初期の強度発現は大きいが, 材令 3 日以後の強度は稻や かに増進する. この漸増する強度増加は, 懸濁するセメ ントUの水和の進行によると考えられる.

一般に, セメント硬化体の強度はセメントと空隙（練 り混ぜ水量十空隙量) の容積比に支配される. 図一4 は この考えに従って, CM 系の間隙内部のセメント空陌 比, すなわち, セメント水比メてん充率を求め, 材令 28 日の試験値を整理したものである. 多少の変動はあ るものの, CM 系の一軸圧縮強さとセメント空陌比と の関係は, 全体的にほぼひとつの相関直線で表せられる ようである. 次に, 図一 5 に LW 系グラウトの強度と てん充率の関係を示す. LM-4の方が LW-8 より全体 的に強度が高いのは, セメントおよび水ガラスの単位量 の多いホモゲル (以下, CM 系, LW 系いずれも，グ ラウト自体の硬化体をホモゲル称する) の力学的特性が 


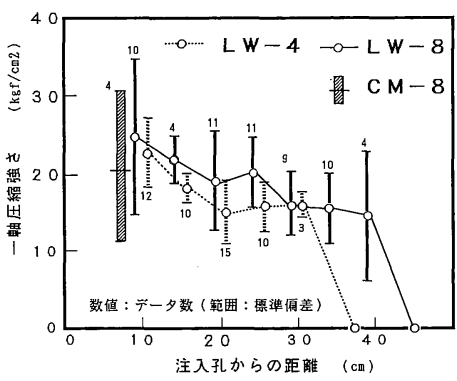

図一7 掘出し固結体の注入孔からの距離之 一軸圧縮強さ

強度上有利に作用しているためと考えられる。また，て ん充率との相関がみられないことは，セメント空隙比理 論が成立しないことおよびホモゲルの強度機構が, 空隙 量に敏感な脆性材料のそれ之異なることを示している. すなわち，今回の実験の範囲では， $\mathrm{CM}$ 系の強度を左 右する要因は空隙比に関係する結合材の絶対量（セメン 卜量) であり，また，LW 系ではホモゲルの絶対量よ りはそれ自体の強度, 変形性なざの力学性状が強度の支 配因子となっていると考えられる.

現場実験における LW 系グラウト 2 種の注入孔から の距離とセメント分および水ガラス分の含有率の関係を 図一6にプロットした．ここで，これらの含有率はそれ ぞ机， Ca成分， Na成分の化学分析によるものであり, 設定配合グラウトが空隙を完全に充てんする状態の濃度 を基準として百分率表示したものである.なお，この值 の変動は成分構成比あるいはてん充率の変化を示すこと になる. 図中, 固結体の表面位置（注入孔からの距離を 平均円筒半径亡仮定）における含有率は，0上みなして いる. また, 参考のため, 前章で求めた平均てん充率 (総 注入量／固結体の総空隙量）も図中に併記した. 図から 明らかなように，水ガラスはセメントの場合と比べて， $30 \mathrm{~cm}$ 以内では含有率の変化が少ない。この範囲では含 有率が $80 \%$ 程度に低下しているが，原因が未充てん部 の存在か地下水の希釈によるものか明かでない，一方， セメントの含有率は注入孔からの距離に応じて急激に減 少している．また，注入孔に近いところでは含有率が $100 \%$ を越えている．このことは，セメントの土粒子間 隙への拘留が著しく, 注入孔に近いところで目詰まりと 濃縮が生じたことを示している。この現象はセメント濃 度の高い LW-4 の方が LW-8 よりも特徵的である.こ のようなセメント含有率の距離による低減は，図一7に 示すごとく, 注入孔からの距離と一軸圧縮強さの関係之 相似しており，セメント含有率が強度に及ぼす影響が大 きいことがわかる，なお，図一7において，含有率の場 合と同様に, 固結体表面 (平均円筒半径位置) での強さ は 0 とみなしている。

ところで, LW 系についての混合成形供試体ではセ

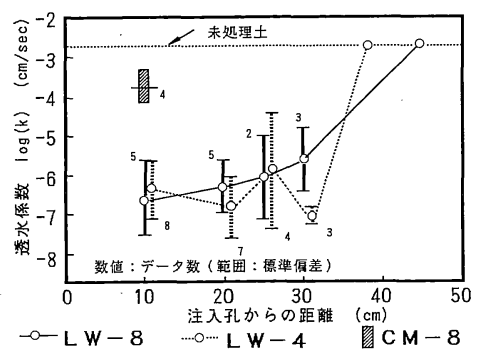

図一9 掘出し固結体の注入孔からの距離之透水係数

メント含有率の影響がみられず，一方，現場注入処理土 ではセメント含有率が強度にかなり影響した理由および 混合成形よりも現場注入の方が強度が高い理由は，注入 によった場合，試験材令の違いのほかに後述の間隙内部 の形態観察にみられるように，セメントが土粒子の接合 部に集中して拘留され，この補強効果が水ガラスの補強 効果なよ゙よりも卓越したためと考えられる。また, 現場 注入の水ガラス含有率が強さに及ぼす影響が不明瞭なの は，未充てん部分の存在および地下水の希釈によるホモ ゲルの力学性状の低下などにより, 水ガラスの補強効果 が相対的に低下したためと考えられる.

LW-4 の単位セメント量は LW-8より若干多いが, このため目詰まりによるセメント含有率の変化が生じ易 いようであり, LW-4 と LW-8 の強度は, 図一7にみ られるように注入孔付近での強度差は少ないものの, 注 入孔から離れるにつれて LW-4 の方の強度が低くなっ ている。なお，単位セメント量の多い CM-8 の強度が LW 系より若干低い理由は明らかでないが，セメント の不均一な浸透が原因の一つ之推察される.

\section{( 2 ) 透水係数}

図-8 に混合成形供試体の材令 7 日, 28 日の透水係数 を示す．材令 28 日の透水係数は, $\mathrm{CM}$ 系では水セメン 卜比が小さいほざ，LW 系ではセメントおよび水ガラ ス濃度が高い方が改良されている，全体的に CM 系よ りも LW 系の方が透水係数は低減されるようであるが, $\mathrm{CM}$ 系では材令の進むことによる改良効果が大きい. 限られた範囲ではあるが, 設定てん充率を, $\mathrm{CM}$ 系で は $75 \%$ ，LW 系では $50 \%$ に低下させると透水性の改良 効果は急激に小さくなり, 材令が進んでも改善されない ようである. 図一9は掘出し固結体の透水係数之注入孔 からの距離の関係を示すものである. 強度の場合と同様 に，固結体表面での透水係数は未処理土と変らないもの とみなして図中に示した。このように透水性改良効果に ついても, 強度補強効果の場合と同様に注入孔に近い方 が改良されている傾向がみられる.

混合成形供武体よりも現場注入固結体の方が透水係数 の改良度は小さいが, この理由は, 現場固結体ではグラ ウトの未充てん部分があることおよび間隙てん充状況が 
不均一であることによると考えられる. 図一7，9に示 すように，CM-8の強度はLW 系と大差がないのに， 透水係数は LW 系よりもかなり大きい。このことは前 章で述べたように CM-8のセメントが土粒子接合部に 集中するため，強度にはあまり影響しないが，内部間隙 が不均一で空孔の多い形態となっているため透水性には 不利になっていることを意味している。

\section{5. 間隙浸透形態に関する微視的検討}

\section{(1) ポロシティ}

a) 試料土のポロシティ

A 地区の試料土のポロシティを図一10に示す。この 試験では乱した試料を用いたので現場土の間隙分布と異 なることが想定されるが，写真—2，a）に示すように， 粒径が均一であること，および細粒分が少ないこと，な ビから間隙分布は大略相似すると考えた。ただし，試料 の詰め方を現場土に近い乾燥密度 $1.40 \mathrm{~g} / \mathrm{cm}^{3}$ とした場 合の間隙分布ピーク位置は後出の混合成形体や現場固結 体よりもやや粗大側にシフトするようである。さらに密 に $\left(1.51 \mathrm{~g} / \mathrm{cm}^{3}\right)$ に詰めた方が実際に近づくようであり， 今後の検討が必要であるが，いずれも粗大部の間隙分布 のピークのみが目立ち，そのピークは半径約 10〜 $60 \mu \mathrm{m}$ の比較的狭い範囲にほぼ含まれた。前章で，グラウタビ リティの判定のために試料土の加積通過 $15 \%$ 径（表一1 参照， $170 \mu \mathrm{m} ）$ をグラウトが浸透する空孔の代表径と みなしたが，このポロシティ測定によれば，緩い充てん の場合でも, 平均間隙直径は約 $60 \mu \mathrm{m}$ であり, 加積通 過 $15 \%$ 径よりもかなり小さい. グラウタビリティを判 定する場合には，グラウト対象土の空孔をこのようなポ ロシティ測定などによって直接求める方が判定の精度の 面で好ましいと考えられる。なお，この平均間隙直径之 セメントの加積通過 $85 \%$ 径との比は，セメントUで 9.7，Fで2.7，Nで 1.7 であり，F，Nの貧弱な固結 体形状から，この比が 3 前後を境として浸透注入が困難 になると推察される。また，Uを用いた LW 系と CM 系の比較から, 浸透性の検討には，この比率だけでなく， 水ガラス等を用いるこよによる潤滑効果, 間隙通過性の 向上も併せて考慮する必要がある.

b) 混合成形供試体のポロシティ

図一11に水セメント比の異なる CM 系混合成形供試 体の間隙径分布を示す。この混合成形供試体や現場注入 固結体の場合を含めて，ほとんど全ての間隙径分布は， 半径約 $0.5 \mu \mathrm{m}$ を境に 2 つのピークを有するのが観察さ れた. 前述の図一10のグラウト未処理土の間隙径分布 形との相違から, 半径 $0.5 \mu \mathrm{m}$ 以下の微細な間隙におけ るピークはホモゲルに由来するものと考えられる.また， 粗大な間隙域のピーク位置およびピーク高さが試料土の それに近いほど，土粒子間の間隙がグラウトによって十
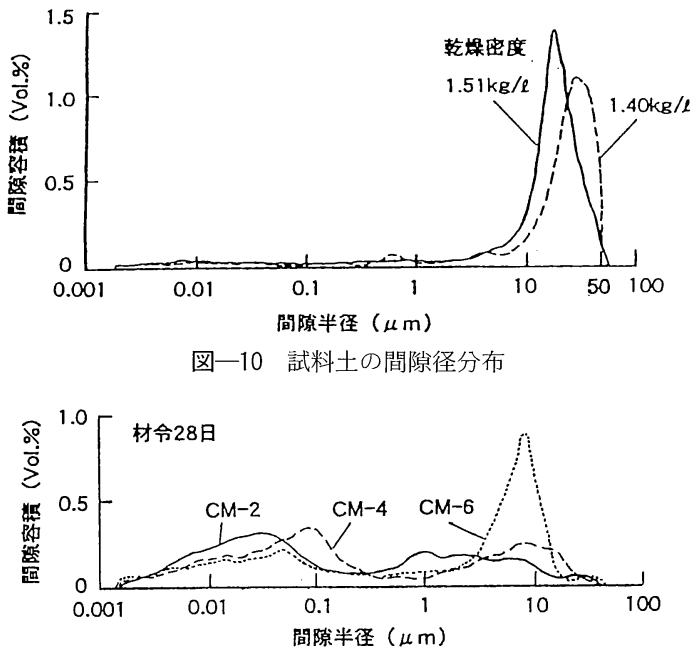

図一11 混合成形供試体 (CM 系)の水セメント比と間隙径分布

分充てんされずに残存していることを意味している．図 一11に示すように， CM 系では水セメント比が小さく なるにつれて (CM-6 $\rightarrow \mathrm{CM}-4)$ ，粗大な間隙径の大幅 な減少および微細な間隙の増加がみられた. また，水セ メント比をさらに小さくすると $(\mathrm{CM}-4 \rightarrow \mathrm{CM}-2)$, ふ たつのピーク位置がそれぞれ小径側にシフトするのがみ られた. CM-2 の, 間隙半径 $1 \mu \mathrm{m}$ を中心とする穏やか なピークは, 後述のグラウト充てん模式図に示すように, セメント粒子間の粗大キャピラリー空隙（図一19の記 号，p.vおよびc. v) や土粒子間の狭小間隙に相当する ものであり，水セメント比が小さい場合，あるいは目詰 りでセメント濃度が高まった場合には，この部分の間隙 が増加すると想定される. また, 間隙半径 $0.5 \mu \mathrm{m}$ 以下 のピークはセメント粒子および水和物間の微細キャピラ リー空陌（図一19の記号, c. v ）であり, 間隙半径 $0.005 \mu \mathrm{m}$ 以下は水和物間のゲル空隙に相当するもので あると考えられる5!

図一12 は濃度の異なる LW 系の間隙径分布を示すも のである。これらの粗大間隙部のピーク高さは, LW-4 よりも LW-8の方が小さいが, この理由は, 現時点で は明らかでない。セメントー水ガラス系を含み，各種の 水ガラスの硬化反応およびホモゲルの性質は不明な点が 多く，その解明は今後の課題である ${ }^{6)}$. ところで，微細 な間隙部分では，LW-8よりも LW-4の方が，ピーク 位置がより微細な方にシフトするとともに，分布幅が狭 くなっている.この部分は, 先述の微小キャピラリ一空 隙に相当しており，セメント濃度の高い LW-4 の方が 緻密な水和物, すなわち密実な充てん構造を形成してい ることを示している。

次に, CM 系亡 LW 系の間隙径分布の材令变化の一例 （てん充率 100\%）を図一13および図一14に示す．両 グラウトともに，材令の経過につれて土粒子間に形成さ 


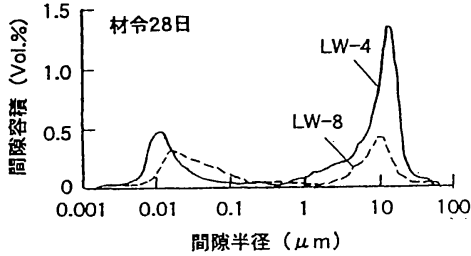

図-12 混合成形供試体 (LW 系) の濃度と間陌径分布

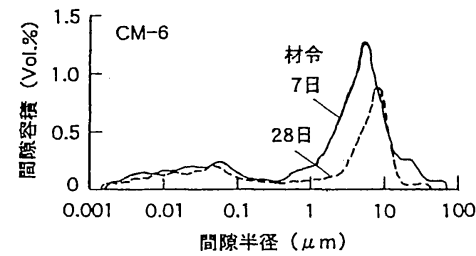

図-13 混合成形供試体 (CM-6) の間隙径分布の材令変化

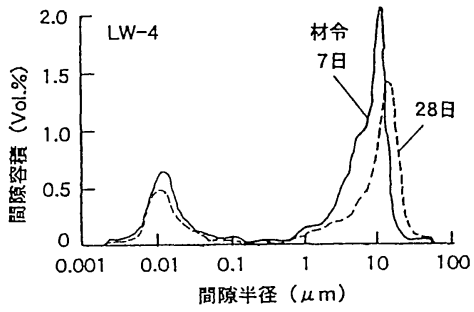

図-14 混合成形供試体 (LW-4) の間陌径分布の材令変化
れる粗大間隙部のピーク高さが減少した.この減少の状 況は，粗大間隙の中でも相対的に小さい間隙（0.5〜10 $\mu \mathrm{m})$ の方が減少量が大きい，このことは，模式図（図 一19a)）に示すような土粒子接合部近辺および粗大キャ ピラリ一空隙などの間陌の狭い部分が，セメントの水和 物 (セメントゲル) の発達に伴って, 次第に充てんされ てゆくことを意味している.

c）現場注入固結体のポロシティ

図一15に，グラウト処理後に掘出した固結体 (LW-4) について, 注入孔からの距離を変えて採取した試料の間 隙径分布を示す：注入孔付近（注入孔から $10 \mathrm{~mm}$ )。の 試料には土粒子間に形成される粗大な間隙がほとんど存 在していないことから，大部分はホモゲルの固結体であ ることが想定される. また，注入孔から $30 〜 70 \mathrm{~mm}$ の 試料は $1 \mu \mathrm{m}$ 前後の間隙半径にもピークがあるが，この ような間隙寸法は先述のセメント粒子間の粗大キャピラ リ一空陌に相当しており，これから土粒子間をかなり高 濃度でセメントが充満していることが推察される.なお, 注入孔からの距離が大きいほぼ, 粗大間隙部のピークが 目立っており，これはグラウト充てん量が少ないため， 土粒子の元の骨格が反映されていることを示している.

d）間隙容積と一軸圧縮強さの関係

混合成形供試体（てん充率 100\%) の間隙容積（ポロ シティ測定で得られる試料単位容積当りの空隙容積）と 一軸圧縮強さとの関係を図一16 (CM 系) および図一 17 (LW 系) に示す.これらの図中データは単位セメ ント量および材令の違いを含むものであるが，CM 系 については, 両者の間に密接な関係が認められ, 全間隙 量が減少し，逆にセメント水和物に由来する微細な間隙 量が増加（特に，半径 $0.5 \mu \mathrm{m}$ 以下）するにつれて固結 体の一軸圧縮強さが指数的に高くなっている．この系の グラウトでは，土粒子間陌へのセメント粒子の充てんお よびその後のセメントの水和反応による組織の緻密化が 強度発現の支配的要素であると考えられる. 一方, LW 系では, 間隙量と一軸圧縮強さとの間には CM 系ほよ゙ の明瞭な関係は認められなかった。このように，水銀圧 入ポロシティ一測定法で得られる空隙量と一軸圧縮強さ との間に相関が無いことは, 前章のてん充率の場合と同 様であり，セメント一水ガラス系グラウトで固結させた
処理土の一軸圧縮強さは, 脆性材料のように結合材空隙 比の因子で説明できないことを重ねて意味している.

e）間隙容積と透水係数との関係

図-18にCM 系混合成形供試体（てん充率 100\%) の間隙量と透水係数との関係を示す.一軸圧縮強さの場 合之同様に，間隙量亡透水係数との間には密接な関係が あり，透水係数は全間隙量に比例している．全間陌のほ とんどは大きな間隙部の量に等しいので, 締固め処理土 の透水係数は 1 20 $\mu \mathrm{m}$ 程度の大きな間隙量に比例する との従来の指摘 ${ }^{1}$ とも一致している. また, セメント水 和物に由来する半径 $0.5 \mu \mathrm{m}$ 以下の微細な間隙量が増加 するほ亡゙,透水係数が減少する傾向が明瞭に認められる. なお， LW 系の間陌量と透水係数之の間には CM 系の ような相関関係は認められなかった. LW 系では, 木 モゲル中の水ガラス硬化体が不透水性の連続構造である ことが透水係数を小さくする要素と考えられる. また， 前章でも示したようにてん充率が極端に小さくならない 限り, 透水係数改良効果の大幅な低下はみられない.こ のことから, LW 系では, 後述の電子顕微鏡写真に見 られるように多少の未充てん部分が存在しても, それら の間隙がホモゲルの連続体によって独立状態に保持され るため透水性改良効果が損なわれることが少ないと考え られる。

\section{（2）微細組織の観察}

\section{a) 光学顕微鏡観察}

写真一1 は, 混合成形供試体および掘出し固結体から 薄片を作製し,その光学顕微鏡写真を示したものである. $\mathrm{CM}$ 系の混合成形供試体（写真一1 a ））ではセメント粒 子は土粒子の間隙部分の一方に偏して分布している.こ れはグラウトが硬化に至るまでのセメント粒子の分離沈 降により，鉛直下方にセメントが堆積（記号 A）し， 上方に空隙（記号 B）が生じた結果によると考えられ る (図一19a-1) 参照). 同じ CM 系の掘出し固結体 (写 真一1 c)）では，土粒子の接触部などの比較的狭い間陌 部にセメント粒子が集中（記号 C）している.このよ うな不均一な懸濁粒子の分布は目詰りが原因と考えら れ, 注入浸透の場合の特徵とみなされる（図一19a-2） 参照). LW 系の混合供試体 (写真一1 b ) ) については 土粒子間に丸みを帯びた水ガラスゲル（記号 D）と思 


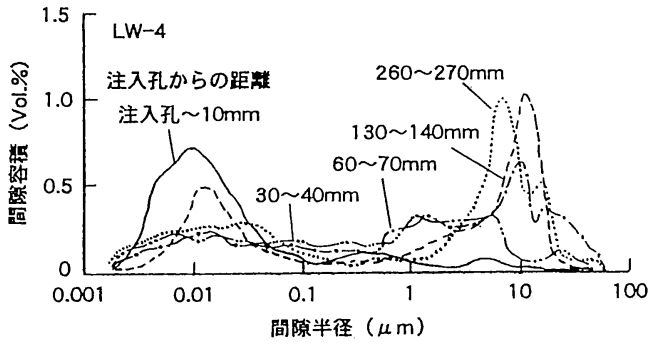

図一15 掘出し固結体 (LW-4) の間隙径分布

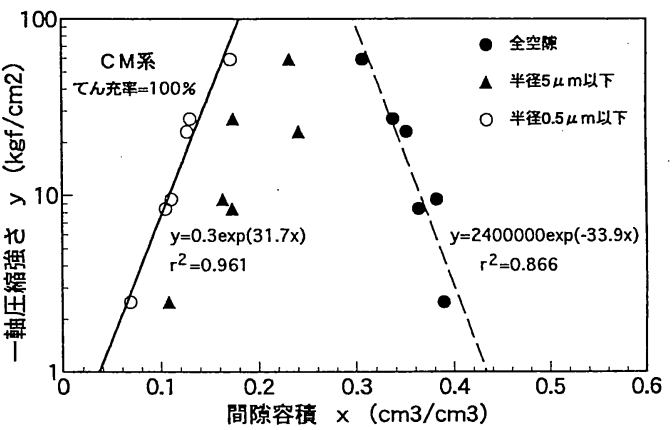

図一16 混合成形供試体 ( $\mathrm{CM}$ 系) の間隙容積と一軸圧縮強さ

われる組織が多数観察された.また，セメント粒子はそ の濃度が希薄なこともあって容易に識別できないほどに 均一に分散している. 一方, LW 系の掘出し注入固結 体 $($ 写真一1d)）については，前述のような水ガラスゲ ルの境界が明瞭に識別できず，セメント粒子あるいはそ の水和物と思われる微細な粒子が土粒子表面付近に集中 している様子が観察された。これは，模式図の図一19 b-1)，b-2）に示すように，狭い土粒子間の隙間をグラ ウトが通過する際に, 球状の水ガラスが集合変形・一体 化して連続体となり，土粒子表面を濡らすような状態で 浸透することによるものと推察される. 土粒子周辺部へ のセメントの集中は，この挙動に伴ったもの，あるいは $\mathrm{CM}$ 系の場合亡同様に，注入浸透の際の目詰まり拘留 によるもの，亡想定される．なお，土粒子周辺部へのセ メントの集中は土粒子の接触部の強化に結びつき, 固結 体の強度を向上させることに寄与すると考えられる.

c）低真空走査型電子顕微鏡観察

ホモゲル, 特に水ガラスゲルは乾燥などに敏感であり, ポロシティ試料の前処理および光学顕微鏡薄片試料作成 時の乾燥過程，あるいは長期試料の保存時にホモゲルの 変質の可能性が存在した．そこで，試料作製から観察実 施までの期間をできるだけ短縮するとともに，乾燥の影 響を極力防止するために，実験室でグラウトを浸透させ た固結体を製作し，観察直前まで湿潤状態に保持した試 料破断面を低真空走査型電子顕微鏡観察で観察した. 写 真一2 に観察結果の一例（材令 10 日）を示す.

浸透した CM 系グラウト (CM-4) 中のセメント粒 子は土粒子間の狭い間隙に局所的に拘留されていること

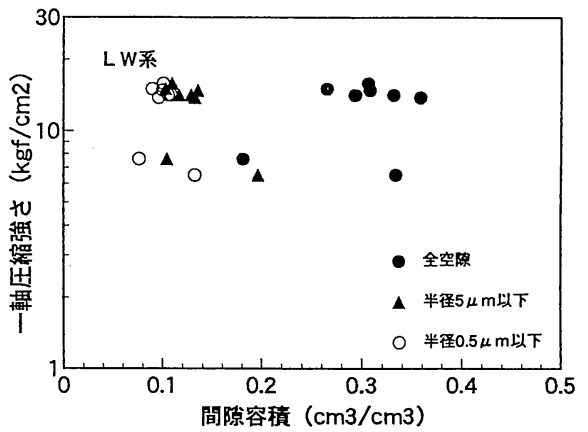

図一17 混合成形供試体（LW 系）の間隙容積之一軸圧縮強さ

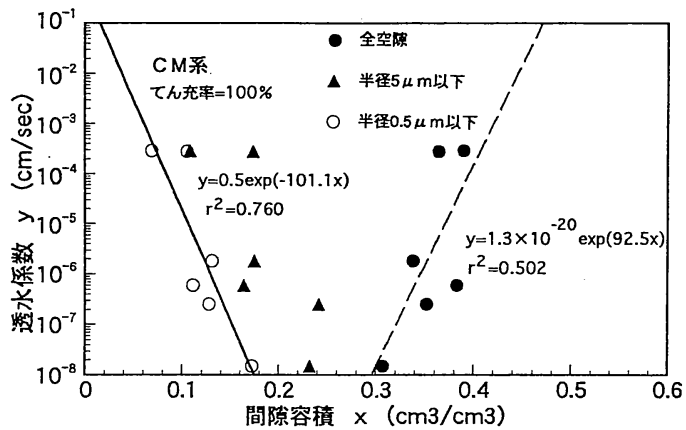

図一18 混合成形供試体 ( $\mathrm{CM}$ 系) の間隙容積と透水係数

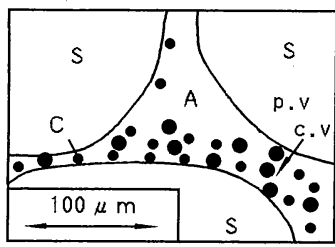

a-1）混合成形

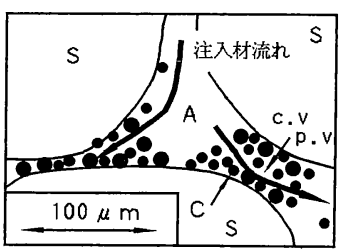

a-2) 注入処理土

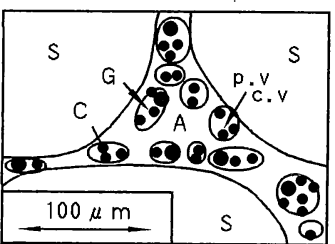

b-1）混合成形

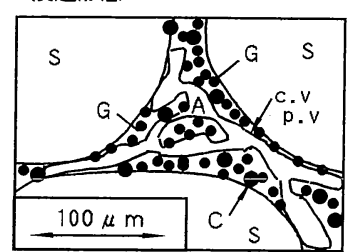

b-2）注入処理土 b) LW系の充てん・浸透形態

$S$ :土粒子 C:セメント粒子 $A$ :空隙 $G$ : 水ガラスゲル

p. v:セメント粒子閒隙 c.v:キャピラリー空隙

図一19 グラウトの間隙充てん・浸透形態についての模式図

や液相反応で生成した針状水和物（エトリンガイト）が 土粒子の表面に多数生成しているのが観察された（写真 一2b）および c)). また，この CM-4では土粒子間の 粗大な連続間隙がかなり残存しており,この部分を通じ てグラウトが伝搬されたものと思われる. なお, 注入直 後にはこの部分にもグラウトが充満していたと考えられ るが，その後の懸濁物質の分離沈降などにより，セメン 卜粒子などは土粒子表面に移動し，水分の多い空隙が残 


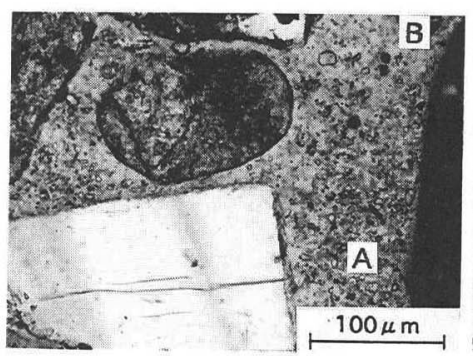

a) 混合成形供試体 (CM-6)

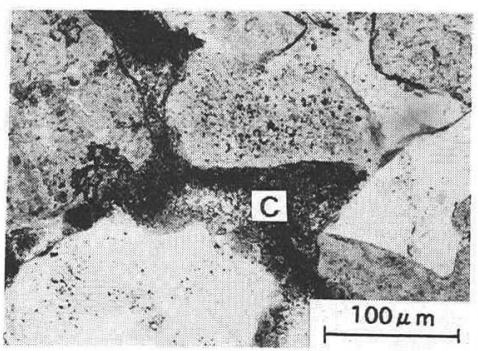

b) 混合成形供試体（LW-4）

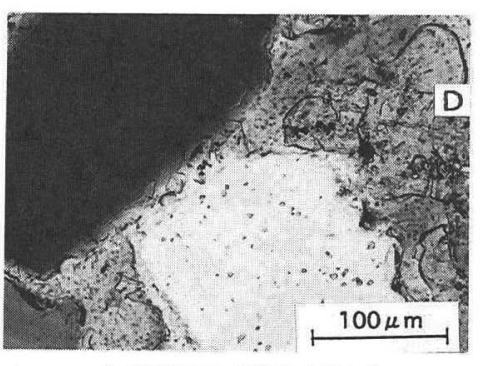

c) 現場掘出し固結体 (CM-8)

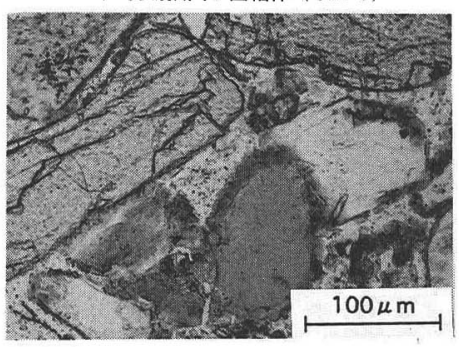

d）現場掘出し固結体 ( LW-8)

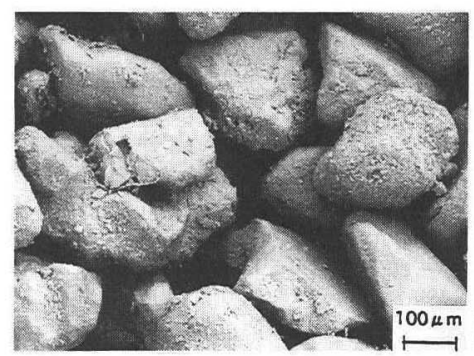

a) 武料士 (グラウト米注人)

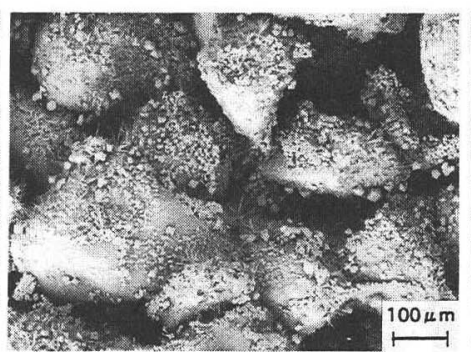

b）グラウト浸透供武体 (CM-4)

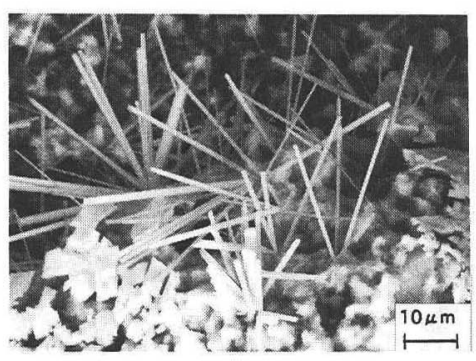

c) グラウト浸透供試体 ( $\mathrm{CM}-4)$

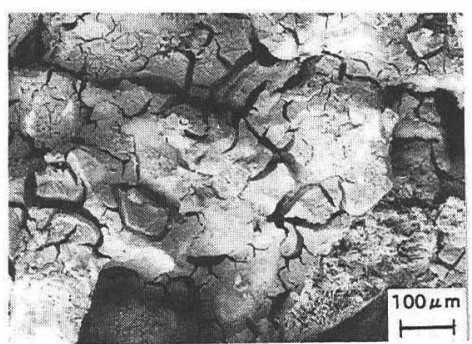

d）グラウト浸透供試体（LW-4）
写真一2 試料土およびグラウト浸透供試体破断面(実験室注入， 材令 10 日）の電子頙微鏡写真
組織は非常に鋭敏であるので，この組織をあるがままに 観察する手法の開発が今後の課題しして挙げられる.

\section{6. ま と め}

従来, 懸濁系グラウトの注入は困難とされていたシル ト混じり砂質土を試験地に選び, 現場注入実験および室 内実験等を実施し, セメントミルクおよびセメントー水 ガラス系グラウトの浸透性, 固結体の工学的性質につい ての実験研究および内部浸透形態の微視的観察等を行っ た. 本研究の結果は, 以下のようにまとめられる.

（1）水銀圧入式ポロシメーターで試料土の間隙寸法お て生じたものである.このように水ガラス系のホモゲル 
よびその分布の大略を求めることができた.

（2）上記の間隙寸法とセメントミルクの浸透性の関係 加ら，セメント粒径の加積通過 $85 \%$ 径に対し，間隙平 均直径が 3 倍前後を境として浸透が困難になるとの指標 を得た。

（３）セメントー水ガラス系グラウトはセメントミルク よりも浸透性が優れ, 大きな固結体を得ることができた. この原因は，懸濁物質の分離沈降が少ないことおよび水 ガラスの潤滑作用によるものと想定された.

（4）セメント-水ガラス系グラウト注入固結体中のセ メント含有率は, 注入孔付近で高く, 注入孔から離れる ほど低下するのに対し, 水ガラス含有率は, ある範囲 $(30$ $\mathrm{cm}$ 程度）まで比較的均一であることがわかった。

（5）上記の含有率の変化は，一軸圧縮強さおよび透水 係数などの工学的性質と対応していた。

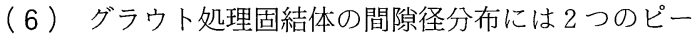
クが観察され，粗大間隙部のピークは土粒子間の間陌に 対応し, 微小間隙部のピークはホモゲルの微細構造に由 来していると考えられた.

（7）セメントミルク固結体の粗大間隙容積は, 水セメ ント比が小さいほど，材令が進むほよ゙，あるいはてん充 率が大きいほど減少する。

（8）セメントミルク固結体の半径 $0.5 \mu \mathrm{m}$ 以下の間隙 量と一軸圧縮強さおよび透水係数との間には強い相関が 認められた。

（9）セメントミルク固結体のセメント空隙比と一軸圧 縮強さとの間には直線的相関関係がみられた.

（10）セメント-水ガラス系グラウト固化体の一軸圧縮 強さおよび透水係数は, セメントミルクの場合のように, ポロシティやてん充率等との相関が認められない.

（11）グラウト中のセメントは注入浸透の際，土粒子間 の砂粒子の接触部に集中して拘留される.このため, 補 強効果は有効に発揮されるものの，てん充状況が不均一
になるため, 本研究のように，単純なセメントと水から なるグラウトの場合には，透水性の改良効果が十分でな いこともある.

（12）セメント-水ガラス系グラウトは土粒子間の間隙 内部で空隙を埋め尽くすように充てんしており，残存す る空隙も不連続構造となっているようである.このため, 透水性の改良効果が高いものと考えられる.

（13）水ガラスのゲル組織は乾燥などに非常に鋭敏であ り，この組織をあるがままに観察する手法の開発が望ま れる.

最後に, グラウト固結体の現場掘り出し調查に際して は，佐藤工業株式会社および（社）楽液注入協会の関係 者の多大の協力を得た. 記して謝意を表する次第である.

参 考 文 献

1）草野一人編：薬液注入工法ハンドブック, pp. 18〜20, 産業図書 (吉井書店刊), 平成 4 年第 5 版.

2）森 麟・田村昌仁・青木康司：超微粒子注入材の浸透限 界, 土木学会論文集, No. $426 / \mathrm{V}-14$ (ノート), pp. 237 ～240, 1991.2.

3）佐藤 健 - 曽場昭之 ·桑山 忠 - 宇野尚雄 : 水銀圧入式 ポロシメーターによる粒状材料の間隙径分布の測定，土 木学会論文集, No.445／III-18，pp.139１42，1992.3.

4）米田俊一・中川浩二：粒子径を変えた各種セメントグラ ウトの基礎的性質亡浸透性比較, 土木学会論文集, No.462/VI-18, pp.101 110, 1993.3.

5) P.K. Mehta : Concrete ; Structure, Properties, and Materials, Pretice-Hall International Series in Civil Engineering and Engineering Mechanics, 1986.

6）加賀宗彦：注入固結砂強度特性などに関する水ガラス系 注入材のゲル構造, 土木学会論文集, No. $460 / \mathrm{V}-18$, pp.93 102, 1993.3.

7) Garcia-Bengochea, I., Lovell, C.W. and Altschaeffl, A.G. : Pore Distribution and Permeability of Silty Clays, ASCE, Vol.105, No.GT.7, pp.839 856, 1979.

(1993. 7.9 受付)

ENGINEERING PROPERTIES AND MICRO STRUCTURES OF FINE SANDS INJECTED WITH SUSPENSION GROUTS OF ULTRA-FINE GRANULAR CEMENT AND SUPPLEMENTARY WATERGLASS

Shunichi YONEDA, Shigeo OKABAYASHI, Masahito TAMURA and Akira MORI Summary of an in-situ grouting test and a digging survey for cement milk and cementwaterglass suspension with various grain sizes into the natural ground are presented. The fine sand in the ground has been considered as the more difficult grouting, having a coefficient of permeability of the order of $10^{-3} \mathrm{~cm} / \mathrm{sec}$. The relationships between the engineering properties as both permeability and strength and the pore size distribution in the hardened sand are examined. The micro structures of these sand are also determined by means of an electron microscope and a mercury intrusion porosimeter. 